\title{
The Relevance of Civil Procedure Law with Constitutional Rights and Principles
}

\author{
Asst. Prof. Phd. Ayşe Kılınç \\ Afyon Kocatepe Universty Faculty of Law
}

\begin{abstract}
Civil procedure law is a branch of procedural law that stipulates the rules of dispute resolution arising out of certain violations of rights referring to private law. Although regarded as a part of private law, It carries characteristics of public law in relation to It's content of procedural rules. In our legal order, fundamental rights and principles, without exception to procedural law, are generally regulated in the Constitution, In this context, the rights and principles codified in the Constitution, which also influence civil procedural law are essentially the principle of state of law, principle of social state, principle of equality, right to due process, procedural economy, principle of publicity. In this study, the relationship between the constitutional rights and principles mentioned above and civil procedure law will be elaborated.
\end{abstract}

Keywords: civil procedure law, constitutional rights, constitutional principles, fundamental rights of civil procedure, fundamental principles of civil procedure 